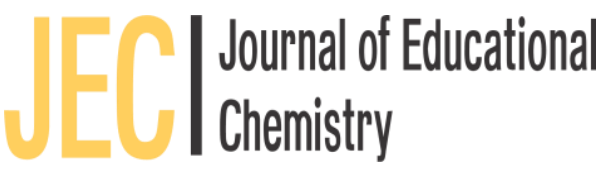

\title{
Analisis Textbooks-For-High-School-Student-Studying-The Sciences-Chemistry Materi Pokok Hidrokarbon Dalam Perspektif Kurikulum 2013
}

\author{
Fika Atina Rizqiana ${ }^{1}$, Mahfudz Siddiq ${ }^{2}$ dan Atik Rahmawati ${ }^{3 *}$ \\ 1,2,3Program Studi Pendidikan Kimia Fakultas Sains dan Teknologi Universitas Islam Negeri Walisongo \\ Semarang, Indonesia \\ *Email: atiks01@gmail.com
}

\begin{abstract}
This study aims to find out the material content of hydrocarbons (completeness of material, accuracy, problem solving, communication, connection, and delivery) in Textbooks For High School Students Studying The Sciences Chemistry published by FHSST Author South Africa and its relevance to the 2013 curriculum for Class X High School. The method of this study is document analysis (documentary analysis) or content analysis (content analysis). Data collection techniques used are documentation and interviews. The results showed that the material completeness was $62.5 \%$ (enough); accuracy of 58.3\% (less); problem solving is 75\% (good); communication of 62.5\% (enough); connection (linkages) of 50\% (less); representations of $62.5 \%$ (sufficient). The relevance between that book with 2013 curriculum is $31.2 \%$ (very less). Based on the results of study, it can be seen that it does not fulfill material content, relevance to the curriculum, and the discussion is incomplete for learning in class X high school.

Keywords: Textbooks Teaching Materials For High School Students Studying The Sciences Chemistry, Hydrocarbon Materials, 2013 Curriculum.
\end{abstract}

22

Copyright (C) 2019 JEC | ISSN 2685-4880

Volume 1, Nomor 1, Juni 2019 


\begin{abstract}
Abstrak
Penelitian ini bertujuan untuk mengetahui sajian materi hidrokarbon (kelengkapan materi, akurasi, pemecahan masalah, komunikasi, koneksi, dan penyampaian) pada bahan ajar Textbooks For High School Students Studying The Sciences Chemistry yang diterbitkan oleh FHSST Author Afrika Selatan serta relevansinya dengan kurikulum 2013 untuk SMA Kelas X. Penelitian dilakukan dengan menggunakan metode analisis dokumen (documentary analysis) atau analisis isi (content analysis). Teknik pengumpulan data yang digunakan yaitu dokumentasi dan wawancara. Hasil penelitian menunjukkan bahwa aspek kelengkapan materi 62,5\% (cukup); akurasi 58,3\% (kurang); pemecahan masalah sebesar 75\% (baik); komunikasi 62,5\% (cukup); koneksi (keterkaitan) 50\% (kurang); penyampaian (represent) 62,5\% (cukup). Adapun relevansi materi hidrokarbon pada Textbooks For High School Students Studying The Sciences Chemistry dengan kurikulum 2013 adalah sebesar 31,2 \% (sangat kurang). Berdasarkan hasil penelitian, dapat diketahui bahwa materi pokok hidrokarbon pada Textbooks For High School Students Studying The Sciences Chemistry terbitan FHSST Authors dari Afrika Selatan tidak memenuhi dari segi isi materi, relevansi dengan kurikulum, dan pembahasannya belum lengkap untuk pembelajaran di SMA kelas X.
\end{abstract}

Kata kunci : Bahan Ajar Textbooks For High School Students Studying The Sciences Chemistry, Materi Hidrokarbon, Kurikulum 2013

\section{Pendahuluan}

Buku teks pelajaran merupakan sumber belajar dan media yang sangat penting untuk mendukung tercapainya kompetensi yang menjadi tujuan pembelajaran (Pusbuk, 2000). Pemilihan dan pemanfaatan buku teks sebagai media sumber pembelajaran yang tepat merupakan faktor pendukung keberhasilan dalam pembelajaran. Pentingnya keberadaan buku teks dalam proses pembelajaran menjadikan guru selaku tenaga pendidik harus cermat dalam memilih dan up to date terhadap perkembangan ilmu pengetahuan yang disajikan dalam suatu buku teks. Banyaknya buku pelajaran yang beredar, khususnya kimia, dapat menyebabkan banyaknya pilihan bagi pengguna buku dalam menentukan buku yang digunakan. Buku teks yang baik adalah buku teks yang dapat membuat siswa ingin, mau, senang mengerjakan apa yang diilustrasikan di dalam buku tersebut. Apalagi bila buku teks tersebut dapat menggiring siswa ke arah penumbuhan motivasi intrinsik (Husen 1997).

Tarigan (1986) menyimpulkan beberapa hal mengenai buku pelajaran adalah sebagai berikut; a) Buku teks itu selalu buku pelajaran yang ditujukan bagi siswa pada jenjang pendidikan tertentu, b) Buku teks itu selalu berkaitan dengan bidang studi tertentu, c) Buku teks itu selalu buku yang standar, d) Buku itu biasanya disusun dan ditulis oleh para pakar (ahli, ekspert) di bidangnya masing-masing, e) Buku teks itu ditulis untuk tujuan instruksional tertentu, f) Buku teks juga biasanya dilengkapi dengan sarana pengajaran, g) Buku teks itu biasanya ditulis untuk jenjang pendidikan tertentu, h) Buku teks itu selalu ditulis untuk menunjang sesuatu progaram pengajaran.

Manfaat yang diperoleh dari buku teks menurut Sunarko (2007) antara lain adalah: a) meningkatkan perhatian dan motifasi belajar, b) memberikan fariasi dalam belajar, c) memberikan struktur yang memudahkan belajar, d) menyajikan 
inti informasi belajar, e) memberikan contohcontoh yang lebih kongret, f) merangsang berfikir analisis, g) memberikan situasi belajar yang tanpa tekanan. Widodo (1993) mengatakan bahwa buku teks dapat dibaca kapanpun, dimanapun dan dapat dimanfaatkan sesuai dengan perkembangan kurikulum. Pemilihan buku teks perlu mempertimbangkan berbagai hal diantaranya yang utama adalah adanya keunggulan buku teks yaitu sebagai sumber informasi, maupun pemberi rangsangan saat diperlukan mengingat penyajian materi tertentu dapat mempengaruhi sikap pembaca. Kemutakhiran tahun terbit dipertimbangkan dalam pemilihan namun yang lebih utama adalah data, dan isi (contain) dari buku teks tersebut.

Kebanyakan buku pelajaran di Indonesia masih menggunakan pengantar bahasa Indonesia. Buku dengan pengantar bahasa asing, khususnya bahasa Inggris, masih terbilang sedikit. Sedangkan perkembangan ilmu pengetahuan yang berjalan sudah sangat pesat dan hasilnya diterbitkan dalam buku-buku berbahasa Inggris sebagai salah satu bahasa internasional, terutama untuk ilmu-ilmu pengetahuan alam, termasuk ilmu Kimia.

Ilmu kimia merupakan ilmu yang diperoleh dan dikembangkan berdasarkan eksperimen untuk mencari jawaban atas pertanyaan apa, mengapa, dan bagaimana gejala-gejala alam, khususnya yang berkaitan dengan zat. Sebagai ilmu sains yang digunakan oleh masyarakat global, banyak referensi-referensi, baik berupa textbook, e-book, maupun artikel berbahasa asing yang memuat materi-materi kimia secara lebih mendetail. Ilmu kimia adalah ilmu yang mempelajari tentang peristiwa atau fenomena yang terjadi di alam, lebih spesifiknya lagi mempelajari tentang materi dan perubahan yang menyertainya(Chang, 2004). Textbook dalam bentuk e-book banyak yang disediakan secara gratis. Bahasa yang sering digunakan kebanyakan adalah bahasa Inggris. Salah satu textbook berbahasa Inggris yang dapat digunakan adalah textbook yang diterbitkan oleh FHSST Author.

FHSST (Free High School Science Text) merupakan sebuah proyek yang membantu memberikan buku teks sains, matematika, serta sosial, secara gratis untuk siswa kelas 10 sampai dengan kelas 12 SMA. Proyek ini merupakan inisiatif dari scienties muda Afrika Selatan, dan mengajak scienties dari seluruh dunia yang ingin berkontribusi dalam penulisan buku semacam ini dengan suka rela (Kalteng, 2013). Tujuan dari pengadaan buku teks yang disebarkan dalam bentuk e-book ini adalah untuk sosial dan bukan komersial. Dibandingkan dengan $e$-book lain yang sejenis, buku teks terbitan FHSST ini dapat diperoleh secara gratis dan legal. Selain itu, konten di dalamnya cukup mudah untuk dipelajari serta bahasa yang digunakan juga tidak terlalu sulit bagi siswa SMA.

Badan Standar Nasional Pendidikan (BSNP) mempunyai kriteria tersendiri untuk buku teks. Sebagaimana dikutip oleh Masnur Muslich, buku teks yang berkualitas wajib memenuhi empat unsur kelayakan, yaitu kelayakan isi, kelayakan penyajian, kelayakan kebahasaan, dan kelayakan kegrafikan. Pada unsur kelayakan isi terdapat tiga indikator yang harus diperhatikan, yaitu kesesuaian uraian materi dengan Kompetensi Inti dan Kompetensi Dasar pada kurikulum, keakuratan materi, dan materi pendukung pelajaran (Muslich, 2010).

Kurikulum 2013 telah banyak digunakan di sekolah baik negeri maupun swasta untuk menggantikan Kurikulum Tingkat Satuan Pendidikan (KTSP). Inti dari Kurikulum 2013 ada pada upaya penyederhanaan, dan tematikintegratif (Kementrian Pendidikan dan Kebudayaan Republik Indonesia, 2013). Pada tahun ajaran baru 2013/2014 yang terhitung mulai tanggal 15 Juli 2013, pemerintah mulai mengimplementasikan Kurikulum 2013 sebagai 
kurikulum pendidikan nasional (tvOneNews, 2013).

Pelaksanaan penyusunan kurikulum 2013 adalah bagian dari melanjutkan pengembangan Kurikulum Berbasis Kompetensi (KBK) yang telah dirintis pada tahun 2004. Isi kurikulum tersebut mencakup kompetensi sikap, pengetahuan, dan keterampilan secara terpadu. Sebagaimana amanat UU 20 Tahun 2003 tentang Sistem Pendidikan Nasional pada penjelasan Pasal 35, di mana kompetensi lulusan merupakan kualifikasi kemampuan lulusan yang mencakup sikap, pengetahuan, dan keterampilan sesuai dengan standar nasional yang telah disepakati. Paparan ini merupakan bagian dari uji publik Kurikulum 2013, yang diharapkan dapat menjaring pendapat dan masukan dari masyarakat.

Salah satu materi yang ada pada mata pelajaran kimia di kelas $\mathrm{X}$ adalah hidrokarbon. Pemahaman konsep dan keterampilan sangat diperlukan dalam mempelajari materi ini. Berdasarkan latar belakang tersebut, peneliti tertarik untuk menganalisis sebuah textbook kimia berbahasa Inggris, dengan berfokus pada materi pokok hidrokarbon, dan menganalisis isi materi serta relevansinya dengan kurikulum 2013.

\section{Metode Penelitian}

Penelitian dilakukan dengan menggunakan metode analisis dokumen (documentary analysis) atau analisis isi (content analysis). Teknik pengumpulan data yang digunakan yaitu dokumentasi dan wawancara. Sumber data yang digunakan adakah bahan ajar textbook yang berjudul Textbooks For High School Students Studying The Sciences Chemistry pada materi hidrokarbon dan kompetensi dasar pelajaran kimia materi hidrokarbon kelas X kurikulum 2013.

\section{Hasil Penelitian dan Pembahasan}

1. Analisis Materi

Aspek yang diamati meliputi kelengkapan materi, akurasi, pemecahan masalah, komunikasi, koneksi (keterkaitan), dan penyampaian atau representasi.

a. Kelengkapan Materi

Pada aspek kelengkapan materi diperoleh persentase sebesar $62,5 \%$ atau pada kriteria cukup. Penyajian materi sudah sesuai dengan urutan sajian, yaitu dimulai dari pengantar tentang hidrokarbon hingga penggolongan senyawa hidrokarbon (alkana, alkena, dan alkuna) beserta tata nama dan reaksi yang terlibat di dalamnya. Akan tetapi, materi yang disajikan hanya mencakup aspek pengetahuan saja.

b. Akurasi

Tingkat akurasi materi hidrokarbon pada textbook yang dianalisis sebesar $58,3 \%$ atau pada kriteria kurang. Berdasarkan analisis, ditemukan adanya ketidakakuratan konsep materi terkait definisi senyawa alifatik dan contoh soal terkait tata nama senyawa alkena.

\section{c. Pemecahan Masalah}

Terdapat 3 subaspek yang dianalisis, yaitu adanya materi atau tugas yang bersifat analisis, penyelesaian soal menggunakan prosedur rutin yang sudah diketahui, dan adanya urutan pemecahan masalah dalam contoh soal. Textbook menyajikan tugas yang bersifat analisis yang mampu mendorong peserta didik berpikir tingkat tinggi. Penyelesaian soal menggunakan prosedur konsep yang telah diketahui dan sesuai dengan urutan pembahasan yang disampaikan. Oleh karena itu, aspek pemecahan maslah yang ada pada textbook ini memiliki kriteria baik dengan persentase sebesar $75 \%$. 
d. Komunikasi

Persentase hasil analisis pada aspek komunikasi adalah 62,5\% atau pada kriteria cukup. Pada aspek ini terdapat 2 subaspek yang dianalisis, yaitu apakah materi mengandung ajakan untuk mendiskusikan masalah dalam materi yang terkait dan apakah materi mengandung refleksi ataukah tidak. Berdasarkan analisis yang dilakukan, materi yang disajikan dalam textbook mengandung ajakan untuk mendiskusikan masalah dalam materi yang terkait dengan cukup komunikatif. Akan tetapi, hal ini belum diimbangi dengan adanya refleksi pada akhir pembahasan materi.

e. Koneksi (Keterkaitan)

Aspek koneksi berkaitan dengan adanya hubungan antara materi yang dipelajari dengan disiplin ilmu yang lain dan dengan hal-hal yang bersifat kontekstual. Dari hasil analisis diketahui bahwa pada sajian materi di tiap submateri tidak ada keterangan koneksi (keterkaitan) antara materi yang dipelajari dengan mata pelajaran yang lain. Texbook hanya menyajikan hubungan antara materi yang dipelajari dengan hal-hal yang bersifat kontekstual. Oleh karena itu, aspek koneksi termasuk dalam kategori kurang dengan persentase sebesar 50\%.

f. Penyampaian (Represent)

Subaspek penyampaian (represent) meliputi ada tidaknya tabel, ilustrasi atau grafik untuk menjelaskan materi dan ketersediaan keterangan peraga yang digunakan dalam materi yang terkait. Dari hasil analisis, persentase yang diperoleh untuk subaspek penyampaian adalah $62,5 \%$ atau termasuk kriteria cukup. Berdasarkan analsisis juga diketahui bahwa pada pembahasan terdapat ilustrasi untuk menjelaskan materi. Sebagian besar ilustrasi yang ditampilkan berupa gambar struktur senyawa, contoh senyawa, skema/ diagram yang berfungsi untuk memperjelas materi yang disampaikan. Namun untuk alat peraga, tidak ada keterangan alat peraga yang tersedia.

2. Relevansi Bahan Ajar dengan Kurikulum 2013

Berdasarkan hasil analisis, diperoleh hasil persentase untuk relevansi textbook dengan kurikulum 2013 adalah sebesar 31,2 \% atau termasuk pada kriteria sangat kurang. Hal ini dikarenakan hanya ada satu Kompetensi Dasar (KD) yang sesuai dengan textbook. Oleh karena itu, dapat disimpulkan bahwa tidak ada relevansi antara materi hidrokarbon yang disajikan dalam textbook dengan kurikulum 2013.

\section{Kesimpulan}

Berdasarkan hasil penelitian, dapat diketahui bahwa materi pokok hidrokarbon pada Textbooks For High School Students Studying The Sciences Chemistry terbitan FHSST Authors dari Afrika Selatan tidak memenuhi dari segi isi materi, relevansi dengan kurikulum, dan pembahasannya belum lengkap untuk pembelajaran di SMA kelas X. Namun, textbook ini dapat dijadikan sebagai referensi pendamping buku teks utama serta dapat menambah pengetahuan istilah kimia dalam bahasa inggris. Selain itu, adanya textbook ini dapat mendorong siswa maupun guru untuk dapat secara bijak memanfaatkan teknologi sebagai media pendidikan untuk memperoleh informasi pengetahuan sebanyak-banyaknya.

\section{Daftar Pustaka}

Chang. (2004). Kimia Dasar Konsep-Konsep Inti Jilid 1. Jakarta : Erlangga

Husen, A. (1998). Telaah Kurikulum Buku Teks Bahasa Indonesia. Jakarta. Departemen Pendidikan dan Kebudayaan. 
Kalteng, U. (2013). Buku Pelajaran Sekolah Gratis dari FHSST (Free High School Science Text). Diakses tanggal 4 Februari 2013 dari http://urip.wordpress.com/2012/10/15/buku -pelajaran-sekolah-gratis-dari-fhsst-free-highschool-science-text/

Kementerian Pendidikan dan Kebudayaan Republik Indonesia. (2013). Uji Publik Kurikulum 2013: Penyederhanaan, TematikIntegratif. Diakses pada 6 Juli 2013 dari http://www.kemdiknas.go.id/kemdikbud/ujipublik-kurikulum-2013-1.

Muslich, M. (2010). Textbook Writing: Dasar-dasar Pemahaman, Penulisan, dan Pemakaian Buku Teks. Jogjakarta: Ar-Ruzz Media.

Pusat Perbukuan. (2005). Standar Mutu Buku Mata Pelajaran Ilmu Sosial. Jakarta : Pusat Perbukuan- Departemen Pendidikan Nasional

Sunarko. (2004). Pemanfaatan Media Dalam Pembelajaran Berbasis Kontekstual (CTL). Semarang : Makalah Seminar Jurusan Geografi UNNES

Taringan. (1986). Telaah Buku Teks SMTA. Jakarta : Depdikbud

tvOneNews. (2013). Kemdikbud Sosialisasikan Kurikulum 2013 di Langsa Aceh. Diakses pada 9 Juli 2013 dari http://nasional.tvonenews.tv/berita/view/720 87/2013/07/04/kemdikbud_sosialiasi_kurikul um_2013_di_langsa_aceh.tvOne (4 Juli 2013). Widodo, T. (1993). Tingkat Keterbacaan Teks : Evaluasi Terhadap Buku Teks Ilmu Kimia Kelas I SMA. Jakarta : Disertasi IKIP Jakarta 